\title{
PELATIHAN PENGEMBANGAN ASESMEN AUTENTIK DALAM IMPLEMENTASI KURIKULUM 2013 DI SEKOLAH DASAR BERBASIS LESSON STUDY BAGI GURU-GURU SD DI KECAMATAN BULELENG
}

\author{
I Nyoman Jampel \\ Universitas Pendidikan Ganesha
}

\begin{abstract}
ABSTRAK
Tujuan dari pelaksanaan P2M ini adalah untuk meningkatkan kemampuan guru (1) merencanakan pembelajaran yang akan dilaksanakan di dalam kelas. Dalam hal ini, pembuatan RPP, LKS, media pembelajaran, dan instrumen evaluasi. Dan (2) melaksanakan proses penilaian dalam implementasi kurikulum 2013 sesuai dengan pasal 19 PP No 19 tahun 2005 tentang Standar Nasional Pendidikan dan Permendiknas no 41 Tahun 2007 tentang standar proses pendidikan. Dengan demikian, bentuk kegiatan pengabdian yang akan dilakukan berupa pendampingan lesson study di sekolah. Secara umum, urutan langkah-langkah rinci lesson study mulai dari tahap merencanakan (plan), melaksanakan (do), dan merefleksi (see). Hasil kegiatan refleksi pada siklus I adalah (1) Dalam bekerja dalam kelompok, terdapat siswa yang tidak bekerja. Hal ini dikarenakan guru model tidak memberikan tugas yang jelas kepada masing-masing siswa dalam satu kelompok. Tugas-tugas dalam kelompok sebagian besar dikerjakan oleh orang yang sama atau satu / dua orang saja. Solusi mungkin untuk pertemuan berikutnya setiap siswa diberikan tugas yang jelas kepada masing-masing kelompok. Ini dilakukan sebelum diskusi kelompok dimulai. (2) Secara umum pembelajaran yang dilaksanakan guru model sudah sangat baik, akan tetapi masih ada beberapa kelemahan yang dapat menyebabkan siswa tidak dapat belajar dengan baik. Siswa tidak ada yang mengacungkan tangan untuk bertanya, apakah karena sudah mengerti atau tidak berani karena ada observer. (3) Banyak siswa tidak dapat bekerja dalam kelompok dan harus menunggu penjelasan dari guru. Hal ini dikarenakan di awal kegiatan guru model kurang memberikan petunjuk diskusi, petunjuk penggunaan alat, dan langkah-langkah yang jelas. Dan (4) Secara garis besar, ketercapaian pembelajaran pada siklus I sudah mencapai $85 \%$. Adapun hasil kegiatan refleksi pada siklus II adalah (1) Secara umum pembelajaran yang dilaksanakan guru model sudah sangat baik dan tujuan pembelajaran yang diharapkan sudah tercapai. (2) Guru model sudah melaksanakan pembelajaran dengan sangat kontekstual sehingga siswa benar-benar memahami materi yang disajikan dan tentunya pembelajaran ini akan sangat bermakna bagi siswa itu sendiri. (3) Siswa sangat antusias mengikuti pembelajaran yang dilaksanakan. Hal ini tidak terlepas dari persiapan yang dilakukan oleh guru model. Pembelajaran sangat kontekstual dan sangat menantang. (4) Siswa sangat termotivasi mengikuti pembelajaran. Hal ini disebabkan pembelajaran yang dilaksanakan mengutamakan partisipasi aktif seluruh siswa untuk bekerja dan belajar dengan baik. (5) Semua siswa dapat belajar dengan baik. Ini tentunya berkat kerja keras guru model untuk mempersiapkan pembelajaran dan perhatian guru dapat mencapai seluruh siswa. Dan (6) Secara garis besar, ketercapaian pembelajaran pada siklus II sudah mencapai $95 \%$.
\end{abstract}

Kata Kunci : Asesmen Autetik, Lesson Study

\section{PENDAHULUAN}

Sumber daya manusia (SDM) merupakan salah satu komponen yang sangat penting bagi Indonesia untuk memajukan dan mensejahterakan masyarakatnya. Sumber daya yang dituntut adalah manusia indonesia yang memiliki wawasan terhadap ilmu pengetahuan, teknologi, dan dapat mengembangkannya dalam kehidupan sehari-hari. Untuk mewujudkannya, diperlukan SDM yang berkualitas.

Untuk menghasilkan SDM yang berkualitas, dapat ditempuh melalui pendidikan yang berkualitas. Pendidikan merupakan suatu kegiatan rekayasa manusia sehingga manusia ikut terlibat dalam menentukan keberhasilan pendidikan demi peningkatan kualitas sumber daya manusia. Kualitas 
pendidikan yang baik dapat menciptakan kehidupan yang cerdas, harmonis, mampu mengelola potensi yang ada, serta dapat bersaing secara sehat, sehingga kesejahteraan seluruh manusia dapat tercapai

Guru merupakan subjek-subjek yang memegang peranan yang sangat besar dalam menentukan kualitas pendidikan. Kualitas pendidikan dapat tercipta jika guru telah melaksanakan tugasnya secara profesional. Daoed Yoesoef (1980) menyatakan bahwa seorang guru mempunyai tiga tugas pokok yaitu tugas profesional, tugas manusiawi, dan tugas kemasyarakatan (civic mission). Jika dikaitkan pembahasan tentang kebudayaan, maka tugas pertama berkaitan dengan logika dan estetika, tugas kedua dan ketiga berkaitan dengan etika. Lebih lanjut, tugas-tugas profesional dari seorang guru, yaitu meneruskan atau transmisi ilmu pengetahuan, keterampilan, dan nilai-nilai lain yang sejenis yang belum diketahui anak dan seharusnya diketahui oleh anak. Ketika tugas guru itu harus dilaksanakan secara bersama-sama dalam kesatuan organis harmonis dan dinamis.

Selai tugas-tugas diatas, pada pasal 60 UUGD dinyatakan bahwa "Dalam melaksanakan tugas keprofesionalan, guru berkewajiban: merencanakan, melaksanakan proses pembelajaran serta menilai dan mengevaluasi hasil pembelajaran". Artinya, guru dikatakan profesioanl jika mampu melaksanakan kewajiban berkenaan dengan pembelajaan secara baik. Sesuai dengan Peraturan Pemerintah (PP) nomor 19 tahun 2005 tentang Standar Nasional Pendidikan, pada pasal 19 disebutkan bahwa "proses pembelajaran pada satuan pendidikan diselenggaeakan secara interaktif, inspiratif, menyenangkan, menantang, memotivasi peserta didik untuk berpartisipasi aktif serta memberikan ruang yang cukup bagi prakarsa, kreatif, dan kemandirian sesuai bakat, minat, dan perkembangan fisik serta psikologis peserta didik". Ini berarti, guru dituntut mempunyai kemampuan menyeleggarakan pembelajaran yang berkualitas sebagaimana dimaksudkan di atas.
Selanjutnya, menurut Peraturan Menteri Pendidikan Nasional Republik Indonesia Nomor 16 Tahun 2007 Tentang Standar Kualifikasi Akademik dan Kompetensi Guru, "macam-macam kompetensi yang harus dimiliki oleh tenaga guru sebagai tenaga profesional antara lain : kompetensi pedagogik, kepribadian, profesional dan sosial yang diperoleh melalui pendidikan profesi". Keempat kopetensi tersebut terintregasi dalam kinerja guru. Kompetensi pedagogik meliputi pemahaman guru terhadap peserta didik, perancangan dan pelaksanaan pembelajaran, evaluasi hasil belajar, dan pengembangan peserta didik untuk mengaktualisasikan berbagai potensi yang dimilikinya. Kompetensi kepribadian merupakan kemampuan personal yang mencerminkan keprbadian yang mantap, stabil, dewasa,arif,dan berwibawa, menjadi teladan bagi peserta didik, dan berahlak mulia. Kompetensi sosial merupakan kemampuan guru untuk berkomunikasi dan bergaul secara secara efektif dengan peserta didik, sesama pendidik, tenaga kependidikan, orang tua/wali peserta didik, dan masyarakat sekitar. Kompetensi profesional merupakan penguasaan materi pembelajaran secara luas dan mendalam, yang mencakup penguasaan materi kurikulum mata pelajaran di sekolah dan substansi keilmuan yang menaungi materinya, serta penguasaan terhadap struktur dan metodologi keilmuan. Keempat kompetensi tersebut di atas bersifat holistik dan integratif dalam kinerja guru.

Alasan apa urgensinya pengabdian ini dilakukan adalah sudah mulai berlakunya kurikulum 2013 di tingkat SD. Beberapa elemen perubahan pada kurikulum 2013 yaitu perubahan pada standar kompetensi lulusan, standar proses, standar isi dan standar penilaian. Fokus pengembangan kurikulum 2013 adalah: menguranngi/mengintegrasikan mata pelajaran; mengurangi materi pelajaran; menambah jam belajar; penguatan pelaksanaan kurikulum berbasis kompetensi dalam pembelajaran; penguatan pengetahuan, keterampilan dansikap secara holistik dalam pembelajaran; penguatan pembelajaran 
siswa waktif, dari siswa diberi tahu menjadi siswa mencari tahu dari berbagai sumber belajar; penguatan penilaian proses dan hasil; tanggap terhadap perubahan sosial yang terjadi pada tingkat local, nasional dan global.

Selain itu fokus pembelajaran kurikulum 2013 adalah: penguatan pelaksanaan kurikulum berbasis kompetensi dalam pembelajaran; penguatan pengetahuan, keterampilan dan sikap secara holistik dalam pembelajaran; penguatan pembelajaran siswa aktif, dari siswa diberi tahu menjadi siswa menjadi tahu dari berbagai sumber belajar dan penguatan penilaian proses dan hasil. Kurikulum 2013 berupaya agar adanya peningkatan efektifitas pembelajaran dan juga proses pembelajaran yang mendukung kreatifitas. Proses penilaian juga mendukung kreativitas serta membentuk kemampuan pikir order tinggi sejak dini.

Mengacu pada berbagai tugas dan kewajiban guru di atas, maka berbagai upaya telah dilakukan oleh pemerintah untuk meningkatkan profesionalitas guru. Upaya-upaya tersebut diantaranya: 1) meningkatkan kualifikasi dan persyaratan jenjang pendidikan yang dituangkan dalam pasal I UU No 14 Tahun 2005, 2) melalui program sertifikasi yang tertuang dalam pasal I UU No 14 Tahun 2005, 3) melalui pendidikan dalam jabatan, misalnya dalam bentuk pelatiham dan penataran bagi guru-guru melalui proses kegiatan guru (PKG) dan kelompok kerja guru (KKG), 4) melalui peningkatan kesejahteraan guru melalui tunjangan profesi, tunjangan fungsional, dan lainlain, dan 5) melalui pemberian reward (penghargaan) bagi guru-guru berprestasi (Arum, 2007). Dengan langkah-langkah ini diharapkan guru-guru di Indonesia akan semakin profesional.

Untuk meningkatkan kompetensi guru, salah satu langkah inovatif yang dapat diterapkan adalah lesson study. "Lesson study adalah suatu model pembinaan profesi pendidik melalui pengkajian pembelajaran secara kolaboratif dan berkelanjutan berlandaskan prinsisp-prinsip kolegalitas dan mutual learning untuk membangun learning community" ( Rusman,
2010:384). Apabila dicermati definisi Lesson study, maka ditemukan 7 kata kunci yaitu pembinaan profesi, pengkajian pembelajaran, kolaboratif, berkelanjutan, kolegialitas, mutual learning, dan komunitas belajar. Ketujuh kunci tersebut bertujuan untuk melakukan pembinaan profesi pendidik secara berkelanjutan agar terjadi peningkatan profesionalitas pendidik terus menerus yang tercermin dari peningkatan mutu pembelajaran.

Lesson study merupakan model pembinaan profesi guru, yang dalam pelaksanaannya terdiri dari beberapa tahap yang harus dilakukan. Tiga tahapannya, yaitu Plan (merencanakan), Do (melaksanakan), dan See (merefleksi) yang berkelanjutan dan tak pernah berakhir (continous improvement). Tahap perencanaan (Plan) bertujuan untuk merancang pembelajaran yang dapat mendorong peserta didik belajar dalam suasana menyenangkan, sehingga tujuan yang diinginkan dapat dicapai secara efektif melalui aktivitas belajar secara aktif dan kreatif. Perencanaan yang baik tidak dilakukan sendirian tetapi dilakukan bersama. Beberapa orang guru dapat berkolaborasi untuk memperkaya ide-ide. Perencanaan diawali dari analisis permasalahan yang dihadapi dalam pembelajaran. Selanjutnya, guru secara bersama-sama mencari solusi terhadap permasalahan yang dihadapi yang dituangkan dalam rancangan pembelajaran atau lesson plan, teaching materials berupa media pembelajaran dan lembar kerja peserta didik serta metoda evaluasi. Pertemuan-pertemuan yang sering dilakukan para guru dalam rangka perencanaan pembelajaran menyebabkan terbentuknya kolegalitas antara pendidik dengan pendidik lainnya, sehingga tidak ada yang merasa lebih tinggi atau lebih rendah. Mereka berbagi pengalaman dan saling belajar sehingga melalui kegiatankegiatan pertemuan dalam rangka Lesson study ini berbentuk mutual learning (saling belajar).

Berdasarkan paparan di atas, kegiatan pengabdian pada masyarakat mengenai Lesson study dipandang sangat penting dilakukan untuk membantu menyelesaikan masalah yang dihadapi oleh para guru dalam usaha 
meningkatkan kompetisi guru. Dengan meningkatnya kompetisi guru, diharapkan berdampak pada peningkatan dan pengembangan profesionalisme guru.

\section{Analisis Situasi}

SDN 1 dan SDN 2 Sukasada merupakan SD yang menjadi mitra pelaksanaan P2M yang berbasis Lesson study. Rata-rata tiap sekolah jenjang pendidikan yang telah ditempuh para guru di terdiri atas DII, dan S1 (berdasarkan data guru lapor bulan, 2013).

Berdasarkan hasil wawancara dengan beberapa guru, terungkap bahwa: 1) dalam tahap perencanaan pembelajaran yang akan dilaksanakan di dalam kelas, guru jarang sekali mendapat pendampingan dari instansi terkait terutama dalam hal ini, pembuatan RPP, LKS, media pembelajaran, dan instrumen evaluasi, 2) guru-guru kurang mampu melaksanakan proses pembelajaran yang inspiratif, inovatif, menantang, menyenangkan, dan memotivasi peserta didik sesuai dengan pasal 19 PP No 19 tahun 2005 tentang Standar Nasional Pendidikan dan Permendiknas no 41 Tahun 2007 tentang standar proses pendidikan. Pembelajaran yang dilaksanakan terbatas pada pembelajaran konvesional melalui metode ceramah tanya jawab, 3) rendahnya kemampuan guru-guru untuk menilai dan mengevaluasi hasil pembelajaran yang dilakukan. Penilaian yang dilakukan hanya terbatas pada hasil, sedangkan penilaian untuk proses tidak dilaksanakan. Selain itu guru jarang sekali melakukan refleksi terhadap pembelajaran yang telah dilaksanakan.

\section{METODE PELAKSANAAN}

Permasalahan yang telah dirumuskan di atas dapat dipecahkan secara strategis dengan meningkatkan pemahaman dan keterampilan guru sekolah dasar untuk membuat dan mengimplementasikan asesmen autentik berbasis Lesson study. Dengan demikian, bentuk kegiatan pengabdian yang akan dilakukan berupa pendampingan lesson study di sekolah. Secara umum, urutan langkah-langkah rinci lesson study mulai dari tahap merencanakan (plan), melaksanakan (do), dan merefleksi (see) adalah sebagai berikut:

\section{Tahap Perencanaan/ Persiapan}

Pada tahap perencanaan atau persiapan dilakukan pertemuan awal dengan tim setelah sebelumnya dilakukan persiapan-persiapan. Adapun langkahlangkahnya:

a. Guru model menyusun silabus, RPP, LKM, kuis, dan handout berdasarkan model asesmen autentik yang dipilih untuk pelaksanaan pembelajaran pada siklus I dan II.

b. Guru Model mempresentasikan kompetensi yang ingin dicapai, RPP, LKM, kuis, dan handout berdasarkan model asesmen autentik untuk pelaksanaan pembelajaran pada siklus I dan II, pembelajaran dan urutannya yang dipilih di depan tim.

c. Tim memberikan masukan dan saran terkait dengan kegiatan yang akan dilaksanakan. Lembar observasi dikembangkan berdasarkan aspek-aspek penting paedagosis berdasar kompetensi yang hendak dicapai, berkembang menurut kebutuhan dalam siklus berdasarkan model asesmen autentik.

d. Guru model melakukan perbaikan, membuat kesepakatan jumlah siklus, aktifitas pembelajaran mendasarkan RPP (pendahuluan, inti, dan penutup) serta komitmen waktunya bersama. Termasuk teknis untuk melakukan rekaman proses sehingga seluruh aktifitas terdokumentasi dan menjadi layak sebagai sumber pelengkap bahan pembelajaran dalam kegiatan refleksi.

\section{Tahap Pelaksanaan}

Pada tahap pelaksanaan ini, satu mahasiswa dari jurusan PGSD bertugas untuk melakukan perekaman menggunakan kamera digital dan handycam. Pengambilan gambar dilakukan secara menyeluruh kemudian akan dilakukan editing pada beberapa kejadian yang dianggap penting. 
Sementara observer berdiri mengamati siswa belajar. Secara umum langkah kegiatan sebagai berikut:

a. Guru model melaksanakan proses pembelajaran mulai kegiatan pendahuluan, inti, dan penutup. (tim melakukan pengamatan sesuai waktu yang disepakati).

b. Setelah satu kali pengamatan guru bersama tim serumpun melakukan refleksi hasil pengamatan didukung hasil rekaman video utuh pembelajaran.

c. Guru model merencanakan kegiatan berdasarkan hasil refleksi dimana hal-hal yang dirasakan signifikan dan perlu diperbaiki dilakukan perbaikan (dalam kegiatan ini difokuskan kepada kemampuan guru untuk mengantarkan siswa pada kompetensi yang ditetapkan).

d. Guru model kembali melakukan proses pembelajaran dan tim melakukan pengamatan (sesuai jadwal yang disepakati).

e. Guru bersama tim melakukan refleksi kembali seperti pada langkah b sampai d sampai 2 kali proses ( 2 siklus).

\section{Tahap Refleksi}

Pada akhir seluruh proses refleksi keseluruhan dilakukan untuk memetik pelajaran berharga yang bisa diperoleh. Kegiatan refleksi dilakukan menyeluruh dengan:

a. Guru model bersama tim merefleksikan seluruh siklus pembelajaran. dalam session ini akan dilakukan pengkajian menyeluruh terhadap bukti-bukti yang sudah didoumentasikan.

b. Berbagai masukan baik dari tim serta hasil refleksi didokumentasikan sebagai bahan pembelajaran yang akan didiseminasikan ke sekolah SDN 1 dan SDN 2 Sukasada beserta seluruh rekaman proses.

c. Penyusunan laporan secara lengkap dan menyusun bahan untuk sharing pengalaman kepada guru lain di lingkungan SDN 1 dan
SDN 2 Sukasada yang melaksanakan lesson study.

\section{HASIL DAN PEMBAHASAN Hasil}

Lesson study pada mata pelajaran IPA di kelas V SD Lab Undiksha dilaksanakan dalam dua siklus. Adapun jumlah guru yang terlibat sebanyak 4 orang, yang terdiri dari 1 guru model dan 3 observer. Guru model kegiatan lesson study ini bernama Ketut Yayuk Anggreni, S.Pd.SD. Observer yang berasal dari SDN 1 dan SDN 2 Sukasada bernama I Made Arsana, S.Pd., Nyoman Suryasmini, S.Pd., dan Wayan Kurniasih, S.Pd. Sedangkan tim lesson study PGSD yang terlibat yaitu I Wayan Widiana, S.Pd., M.Pd., Drs. I Nyoman Murda, M.Pd., Dra. Ni Nyoman Garminah, M.Pd., I Made Citra Wibawa, S.Pd., M.Pd., dan I Gede Margunayasa, S.Pd., M.Pd.

Secara rinci hasil pelaksanaan lesson study dipaparkan sebagai berikut.

\section{Pelaksanaan Siklus I}

Siklus I kegiatan lesson study pada mata pelajaran IPA di kelas $\mathrm{V}$ SDN 1 dan SDN 2 Sukasada dilaksanakan pada tanggal 4 Oktober 2014. Materi yang dibahas pada siklus ini yaitu tumbuhan hijau dan fotosintesis. Secara lebih rinci pelaksanaan siklus I lesson study dijelaskan sebagai berikut.

\section{a. Tahap perencaan (plan)}

Tahap perencanaan ini diawali dengan melakukan identifikasi kebutuhan dan masalah yang ada dalam proses pembelajaran. Kebutuhan dan permasalahan yang dapat dianalisis dalam pembelajaran, antara lain: karakteristik pokok bahasan, jadwal pelajaran, kompetensi dasar, menyiasati kekurangan fasilitas dan sarana belajar, karakteristik siswa dan suasana kelas, metode/pendekatan pembelajaran, media, alat peraga, evaluasi proses dan hasil belajar.

Setelah itu, guru model menyusun silabus, RPP, dan kuis. Setelah perangkat tersebut selesai, guru model juga berdisikusi dengan guru lain dan kepala sekolah di sekolah tersebut. Ini bertujuan untuk mencari masukan untuk memperbaiki perangkat pembelajaran 
yang dibuat. Guru model juga mempersiapkan alat dan bahan yang akan digunakan dalam kegiatan pembelajaran. Guru model juga mencoba terlebih dahulu kegiatan yang akan dilakukan sehingga akan diketahui secara dini kesulitan atau hambatan yang mungkin akan terjadi ketika siswa melakukan kegiatan tersebut.

\section{b. Tahap pelaksanaan (do)}

Pada tahapan ini terdapat dua kegiatan utama yaitu: (1) kegiatan pelaksanaan pembelajaran yang dilakukan oleh guru model yang disepakati atau atas permintaan sendiri untuk mempraktikkan RPP yang telah disusun bersama Guru memulai pembelajaran dengan mengucapkan salam kepada anak-anak. Kemudian guru mengabsensi siswa. Selanjutnya guru menanyakan apakah siswa sudah membawa alat dan bahan yang ditugaskan guru minggu lalu. Kemudian guru membimbing siswa ke materi yang akan dijelaskan yaitu mengenai tumbuhan hijau dan fotosintesis. Guru menyampaikan kompetensi dan tujuan yang ingin dicapai pada pertemuan kali ini.

Masuk pada kegiatan inti, guru memberikan pertanyaan kepada siswa yaitu coba sebutkan 5 contoh tumbuhan hijau dan mengapa daun tumbuhan berwarna hijau. Kemudian guru meminta siswa untuk duduk siswa untuk berkelompok. Guru memberikan lembar tugas atau lembar percobaan yang harus dikerjakan oleh siswa. Siswa melakukan percobaan sesuai tuntunan yang ada pada lembar percobaan. Dalam melakukan percobaan, guru selalu memantau dan selalu memberikan penjelasan jika ada kelompok yang bertanya. Di samping itu juga, guru selalu membantu kelompok untuk melakukan percobaan. Selesai melakukan percobaan, siswa kemudian menjawab seluruh pertanyaan yang ada pada lembaran percobaan. Tahap selanjutnya adalah siswa menyampaikan hasil diskusi kelompoknya. Siswa secara bergantian menyampaikan hasil diskusi dan kelompok lain yang tidak presentasi mendengarkannya. Di saat ini juga, guru memberikan penguatan-penguatan terhadap konsep-konsep yang sangat penting, misalnya bahwa zat yang diperlukan dalam fotosintesis adalah air dan dibantu oleh siswa matahari. Dan hasil fotosintesis adalah karbohidrat.

Setelah kegiatan terebut selasai, guru membimbing siswa untuk membuat simpulan dari pembelajaran yang sudah dilaksanakan. Kemudian, guru meminta siswa untuk duduk kembali seperti semula dan tidak berkelompok. Guru memberikan kuis atau evaluasi yang dikerjakan secara individu masing-masing siswa. Setelah selesai itu, guru membahas jawaban soal evaluasi tersebut. Tahap terakhir adalah guru mengumpulkan hasil pekerjaan siswa dan sebagai penutup guru mengucapkan salam. Tidak lupa juga guru memberikan tugas kepada siswa untuk dibawa pada pertemuan selanjutnya.

\section{c. Tahap refleksi (see)}

Tahap refleksi dilaksanakan
setelah kegiatan pembelajaran oleh guru model. Tahap refleksi pada siklus I dihadiri oleh guru model, observer dari SD, dan tim lesson study dari PGSD Undiksha. Tahap refleksi ini dibuka oleh moderator dari Tim Lesson Study PGSD Undiksha, kemudian dilanjutkan oleh penyampaian refleksi sendiri oleh guru model dan dilanjutkan oleh observer. Adapun hasil kegiatan refleksi pada siklus I adalah

1. Dalam bekerja dalam kelompok, terdapat siswa yang tidak bekerja. Hal ini dikarenakan guru model tidak memberikan tugas yang jelas kepada masing-masing siswa dalam satu kelompok. Tugas-tugas dalam kelompok sebagian besar dikerjakan oleh orang yang sama atau satu / dua orang saja. Solusi mungkin untuk pertemuan berikutnya setiap siswa diberikan tugas yang jelas kepada masing-masing kelompok. Ini dilakukan sebelum diskusi kelompok dimulai.

2. Secara umum pembelajaran yang dilaksanakan guru model sudah sangat baik, akan tetapi masih ada beberapa kelemahan yang dapat menyebabkan siswa tidak dapat belajar dengan baik. Siswa tidak ada yang mengacungkan tangan untuk bertanya, apakah karena sudah mengerti atau tidak berani karena ada observer. 
3. Banyak siswa tidak dapat bekerja dalam kelompok dan harus menunggu penjelasan dari guru. Hal ini dikarenakan di awal kegiatan guru model kurang memberikan petunjuk diskusi, petunjuk penggunaan alat, dan langkahlangkah yang jelas.

4. Secara garis besar, ketercapaian pembelajaran pada siklus I sudah mencapai $85 \%$.

\section{Pelaksanaan Siklus II}

Siklus II kegiatan lesson study pada mata pelajaran IPA di kelas V SDN 1 dan SDN 2 Sukasada dilaksanakan pada tanggal 11 Oktober 2014. Materi yang dibahas pada siklus ini yaitu tempat menyimpan cadangan makanan. Secara lebih rinci pelaksanaan siklus II lesson study dijelaskan sebagai berikut.

\section{a. Tahap perencaan (plan)}

Pada tahap perencanaan atau persiapan siklus II, guru model menyusun silabus, RPP, dan kuis. Setelah perangkat tersebut selesai, guru model juga berdisikusi dengan guru lain dan kepala sekolah di sekolah tersebut. Ini bertujuan untuk mencari masukan untuk memperbaiki perangkat pembelajaran yang dibuat. Guru model juga mempersiapkan alat dan bahan yang akan digunakan dalam kegiatan pembelajaran. Guru model juga mencoba terlebih dahulu kegiatan yang akan dilakukan sehingga akan diketahui secara dini kesulitan atau hambatan yang mungkin akan terjadi ketika siswa melakukan kegiatan tersebut.

\section{b. Tahap pelaksanaan (do)}

Guru memulai pembelajaran dengan mengucapkan salam kepada anak-anak. Kemudian guru mengabsensi siswa. Selanjutnya guru menanyakan apakah siswa sudah membawa alat dan bahan yang ditugaskan guru minggu lalu. Kemudian guru membimbing siswa ke materi yang akan dijelaskan yaitu mengenai tempat menyimpan cadangan makanan pada tumbuhan. Guru menyampaikan kompetensi dan tujuan yang ingin dicapai pada pertemuan kali ini. Masuk pada kegiatan inti, guru memberikan pertanyaan kepada siswa yaitu coba sebutkan 5 contoh tumbuhan menyimpan cadangan makanan pada buah dan dimana saja tumbuhan dapat menyimpan cadangan makanannya. Kemudian guru meminta siswa untuk duduk siswa untuk berkelompok. Guru memberikan lembar tugas yang harus dikerjakan oleh siswa. Siswa melakukan diskusi sesuai tuntunan yang ada pada lembar percobaan. Dalam melakukan percobaan, guru selalu memantau dan selalu memberikan penjelasan jika ada kelompok yang bertanya. Di samping itu juga, guru selalu membantu kelompok untuk melakukan percobaan. Selesai melakukan percobaan, siswa kemudian menjawab seluruh pertanyaan yang ada pada lembaran percobaan. Tahap selanjutnya adalah siswa menyampaikan hasil diskusi kelompoknya. Siswa secara bergantian menyampaikan hasil diskusi dan kelompok lain yang tidak presentasi mendengarkannya. Di saat ini juga, guru memberikan penguatan-penguatan terhadap konsep-konsep yang sangat penting.

Setelah kegiatan terebut selasai, guru membimbing siswa untuk membuat simpulan dari pembelajaran yang sudah dilaksanakan. Kemudian, guru meminta siswa untuk duduk kembali seperti semula dan tidak berkelompok. Guru memberikan kuis atau evaluasi yang dikerjakan secara individu masing-masing siswa. Setelah selesai itu, guru membahas jawaban soal evaluasi tersebut. Tahap terakhir adalah guru mengumpulkan hasil pekerjaan siswa dan sebagai penutup guru mengucapkan salam. Tidak lupa juga guru memberikan tugas kepada siswa untuk dibawa pada pertemuan selanjutnya.

\section{c. Tahap refleksi (see)}

Tahap refleksi dilaksanakan
setelah kegiatan pembelajaran oleh guru model. Tahap refleksi pada siklus I dihadiri oleh guru model, observer dari SD, dan tim lesson study dari PGSD Undiksha. Tahap refleksi ini dibuka oleh moderator dari Tim Lesson Study PGSD Undiksha, kemudian dilanjutkan oleh penyampaian refleksi sendiri oleh guru model dan dilanjutkan oleh observer. Adapun hasil kegiatan refleksi pada siklus I adalah 
1. Secara umum pembelajaran yang dilaksanakan guru model sudah sangat baik dan tujuan pembelajaran yang diharapkan sudah tercapai.

2. Guru model sudah melaksanakan pembelajaran dengan sangat kontekstual sehingga siswa benarbenar memahami materi yang disajikan dan tentunya pembelajaran ini akan sangat bermakna bagi siswa itu sendiri.

3. Siswa sangat antusias mengikuti pembelajaran yang dilaksanakan. Hal ini tidak terlepas dari persiapan yang dilakukan oleh guru model. Pembelajaran sangat kontekstual dan sangat menantang.

4. Siswa sangat termotivasi mengikuti pembelajaran. Hal ini disebabkan pembelajaran yang dilaksanakan mengutamakan partisipasi aktif seluruh siswa untuk bekerja dan belajar dengan baik.

5. Semua siswa dapat belajar dengan baik. Ini tentunya berkat kerja keras guru model untuk mempersiapkan pembelajaran dan perhatian guru dapat mencapai seluruh siswa.

6. Secara garis besar, ketercapaian pembelajaran pada siklus II sudah mencapai 95\%.

\section{Pembahasan}

"Lesson study adalah suatu model pembinaan profesi pendidik melalui pengkajian pembelajaran secara kolaboratif dan berkelanjutan berlandaskan prinsip-prinsip kolegalitas dan mutual learning untuk membangun learning community" (Rusman, 2010:384). Apabila dicermati definisi Lesson Study maka ditemukan 7 kata kunci yaitu pembinaan profesi, pengkajian pembelajaran, kolaboratif, berkelanjutan, kolegialitas, mutual learning, dan komunitas belajar. Lesson Study bertujuan untuk melakukan pembinaan profesi pendidik secara berkelanjutan agar terjadi peningkatan profesionalitas pendidik terus menerus yang tercermin dari peningkatan mutu pembelajaran. Styler dan Hiebert (dalam Susilo dkk, 2009:3) mengatakan bahwa Lesson study adalah suatu proses kolaboratif pada sekelompok guru ketika mengidentifikasi masalah pembelajaran, merancang suatu skenario pembelajaran (yang meliputi kegiatan mencari buku dan artikel mengenai topik yang akan diajarkan), membelajarkan peserta didik sesuai skenario (salah seorang guru melaksanakan pembelajaran sementara yang lain mengamati), mengevaluasi dan merevisi skenario pembelajaran, membelajarkan lagi skenario pembelajaran yang telah direvisi, mengevaluasi lagi pembelajaran dan membagikan hasilnya dengan guru-guru lain (mendiseminasikannya).

Lesson study merupakan model pembinaan profesi guru dalam pelaksanaannya terdiri dari beberapa tahap yang harus dilakukan. Lesson Study dilaksanakan dalam tiga tahapan, yaitu Plan (merencanakan), Do (melaksanakan), dan See (merefleksi) yang berkelanjutan dan tak pernah berakhir (continous improvement). Tahap perencanaan (Plan) bertujuan untuk merancang pembelajaran yang dapat mendorong siswa belajar dalam suasana menyenangkan sehingga tujuan yang diinginkan dapat dicapai secara efektif melalui aktivitas belajar secara aktif dan kreatif. Perencanaan yang baik tidak dilakukan sendirian tetapi dilakukan bersama. Beberapa orang guru dapat berkolaborasi untuk memperkaya ide-ide. Perencanaan diawali dari analisis permasalahan yang dihadapi dalam pembelajaran. Permasalahan dapat berupa materi bidang studi atau bagaimana menjelaskan suatu konsep. Permasalahan dapat juga menyangkut aspek pedagogi tentang metode pembelajaran yang tepat agar pembelajaran lebih efektif dan efisien atau permasalahan fasilitas belajar, yakni bagaimana mensiasati kekurangan fasilitas pembelajaran. Selanjutnya, guru secara bersama-sama mencari solusi terhadap permasalahan yang dihadapi yang dituangkan dalam rancangan pembelajaran atau lesson plan, teaching materials berupa media pembelajaran dan lembar kerja siswa, serta metode evaluasi. Pertemuan-pertemuan yang sering dilakukan para guru dalam rangka perencanaan pembelajaran menyebabkan terbentuknya kolegalitas antara pendidik 
dengan pendidik lainnya sehingga tidak ada yang merasa lebih tinggi atau lebih rendah. Mereka berbagi pengalaman dan saling belajar sehingga melalui kegiatankegiatan pertemuan dalam rangka Lesson Study ini terbentuk mutual learning (saling belajar).

Langkah kedua dalam Lesson Study adalah pelaksanaan (Do) pembelajaran untuk menerapkan rancangan pembelajaran yang telah dirumuskan bersama. Langkah ini bertujuan untuk mengujicoba efektivitas model pembelajaran yang telah dirancang. Pendidik lain bertindak sebagai pengamat (observer) pembelajaran. Fokus pengamatan ditujukan pada interaksi para peserta didik, peserta didik-bahan ajar, peserta didik-pendidik, dan peserta didiklingkungan yang terkait. Para pengamat dapat melakukan perekaman kegiatan pembelajaran melalui video camera atau foto digital untuk keperluan dokumentasi dan bahan studi lebih lanjut. Keberadaan para pengamat di dalam ruang kelas disamping mengumpulkan informasi juga dimaksudkan untuk belajar dari pembelajaran yang sedang berlangsung dan bukan untuk mengevaluasi pendidik.

Langkah ketiga dalam kegiatan Lesson Study adalah refleksi (See). Setelah selesai pembelajaran langsung dilakukan diskusi antara guru dan pengamat yang dipandu oleh moderator atau personel yang ditunjuk untuk membahas pembelajaran. Guru model mengawali diskusi dengan menyampaikan kesan-kesan dalam melaksanakan pembelajaran. Selanjutnya, pengamat diminta menyampaikan komentar dan lesson learnt dari pembelajaran terutama berkenaan dengan aktivitas peserta didik. Tentunya, kritik dan saran untuk pendidik disampaikan secara bijak demi perbaikan pembelajaran. Sebaliknya, pendidik harus dapat menerima masukan dari pengamat untuk perbaikan pembelajaran berikutnya. Berdasarkan masukan dari diskusi ini dapat dirancang kembali pembelajaran berikutnya.

Ada 8 (delapan) peluang yang dapat diperoleh oleh guru apabila melaksanakan lesson study secara berkesinambungan. Ke-8 peluang tersebut sangat erat kaitannya dengan pengembangan profesionalisme guru. Menurut Lewis (dalam Santyasa, 2009), peluang-peluang tersebut adalah (1) memikirkan dengan cermat mengenai tujuan pembelajaran, materi pokok, dan bidang studi, (2) mengkaji dan mengembangkan pembelajaran yang terbaik yang dapat dikembangkan, (3) memperdalam pengetahuan mengenai materi pokok yang diajarkan, (4) memikirkan secara mendalam tujuan jangka panjang yang akan dicapai yang berkaitan dengan siswa, (5) merancang pembelajaran secara kolaboratif, (6) mengkaji secara cermat cara dan proses belajar serta tingkah laku siswa, (7) mengembangkan pengetahuan pedagogis yang kuat penuh daya, dan (8) melihat hasil pembelajaran sendiri melalui mata siswa dan kolega.

Adapun manfaat yang diperoleh dari kegiatan lesson study adalah: 1) meningkatnya pengetahuan guru tentang materi ajar dan pembelajarannya, 2) meningkatnya pengetahuan guru tentang cara mengobservasi aktifitas belajar siswa, 3) menguatnya hubungan kolegalitas baik antar guru maupun dengan observer lain selain guru, 4) menguatnya hubungan antara pelaksanaan pembelajaran sehari-hari dengan tujuan pembelajaran jangka panjang, 5) meningkatnya motivasi guru untuk senantiasa berkembang, 6) meningkatnya kualitas rencana pembelajaran termasuk komponenkomponennya seperti bahan ajar, teaching materials(hands on) dan strategi pembelajaran (Rusman, 2010:394).

Manfaat lain dari lesson study adalah: 1) menciptakan suasana keakraban dan kekeluargaan antar sesama guru, 2) memberi peluang bagi guru untuk memecahkan masalah dan menciptakan solusinya secara bersamasama serta saling bertukar pengalaman, 3) guru dapat membuat perencanaan pembelajaran secara bersama-sama dan mempraktekan hasil kerjanya, 4) membuat guru menjadi lebih profesional dalam mengajar sehingga menciptakan suasana belajar yang kondusif bagi siswa sebagai tujuan menelurkan siswa-siswa terbaik demi masa depan Indonesia (Anggara \& Umi, 2012). 
DAFTAR PUSTAKA

Anggara dan Umi Chotimah Rian. 2012. Penerapan Lesson Study Berbasis Musyawarah Guru Mata Pelajaran (MGMP) Terhadap Peningkatan Kompetensi Profesional Guru Pkn SMP Se-Kabupaten Organ Ilir. Jurnal Forum Sosial, Vol. V, No. 02, September 2012.

Bali Post. 25 Nopember 2012. Menuntut Profesionalisme Guru pada Hari Guru. Tersedia pada http://www.balipost.co.id/mediadetail .php? module $=$ detailberita\&kid $=$ 10\&id=71932. Diakses pada tanggal 12 Pebruari 2013.

Hendayana, dkk. 2007. Lesson study suatu strategi untuk meningkatkan keprofesionalan pendidik (pengalaman IMSTEP-JICA). UPI Press. Bandung.

Kementerian Pendidikan dan Kebudayaan. 2012. Pengumuman UKG. $\quad$ hhtp://infoukg.kemdikbud.go.id/?id=grafikpelaksanaan\&jenis=ncombo\&level= $1 \& g d x=216 \& i d x=22$. Diperbaharui pada tanggal 21-11-2012 19:59 WIB.

Kemdikbud, 2013a. Materi Pelatihan Guru di SD. Modul Pelatihan Implementasi Kurikulum 2013. Kementerian Pendidikan dan Kebudayaan

Kemdikbud, 2013b. Kompetensi Dasar Sekolah Dasar (SD)/Madrasah Ibtidaiyah (MI). Kementerian Pendidikan dan Kebudayaan

Susilo, dkk. 2009. Lesson Study Berbasis Sekolah Guru Konservatif menuju Guru Inovatif. Malang: Bayumedia Publishing 